\title{
Jetstream and rainfall distribution in the Mediterranean region
}

\author{
M. Gaetani, M. Baldi, G. A. Dalu, and G. Maracchi \\ Institute of Biometeorology, IBIMET, CNR, Rome, Italy \\ Received: 5 September 2010 - Revised: 13 May 2011 - Accepted: 19 May 2011 - Published: 19 September 2011
}

\begin{abstract}
This is a study on the impact of the jetstream in the Euro-Atlantic region on the rainfall distribution in the Mediterranean region; the study, based on data analysis, is restricted to the Mediterranean rainy season, which lasts from September to May. During this season, most of the weather systems originate over the Atlantic, and are carried towards the Mediterranean region by the westerly flow. In the upper troposphere of the Euro-Atlantic region this flow is characterized by two jets: the Atlantic jet, which crosses the ocean with a northeasterly tilt, and the African jet, which flows above the coast of North Africa. This study shows that the cross-jet circulation of the Atlantic jet favors storm activity in its exit region, while the cross-jet circulation of the African jet suppresses this kind of activity in its entrance region, with the 1st jet-stormtrack covariance mode explaining nearly $50 \%$ of the variability. It follows that the rainfall distribution downstream to these cross-jet circulations is strongly influenced by their relative positions. Specifically, in fall, rainfall is abundant in the western Mediterranean basin (WM), when the Atlantic jet is relatively strong but its northeasterly tilt is small, and the African jet is in its easternmost position. In winter, rainfall is abundant in the eastern Mediterranean basin (EM); this is when the Atlantic jet reaches the Scandinavian peninsula and the African jet is in its westernmost position. In spring, when the two jets weaken, the Atlantic jet retreats over the ocean, but the African jet stays in its winter position, rainfall is abundant in the Alpine region and in the Balkans. In addition, the covariance between precipitation and the jetstream has been evaluated. In fall, the latitudinal displacement of the Atlantic jet and the longitudinal displacement of the African jet modulate rainfall anomalies in the WM, with $38 \%$ explained covariance. In winter, the latitudinal displacement
\end{abstract}

Correspondence to: $\mathrm{M}$. Baldi (m.baldi@ibimet.cnr.it) of the Atlantic jet produces rainfall anomalies in the western and central Mediterranean, with $45 \%$ explained covariance. In spring, the latitudinal displacement of the African jet produces rainfall anomalies, with $38 \%$ explained covariance.

\section{Introduction}

The rainfall distribution in the Mediterranean region is important, because this region is at risk of water shortage (Hulme et al., 1999). In fact, an elaboration of the data reported by Marshall et al. (2001a) and by Hurrell (1995) shows that from December to March it rains $30 \%$ more in North Europe than in South Europe. Moreover, since precipitations are almost absent in the Mediterranean region during the summer months, on an annual base the difference between the cumulated rainfall in North Europe and in South Europe is even larger. It follows that the Mediterranean is vulnerable and prone to drought events. This is one of the motivations behind this paper, which is focused on the impact of the jetstream configuration in the Euro-Atlantic region on the rainfall distribution in the Mediterranean region.

In the Mediterranean region the cold season is also the rainy season; from this observational fact the definition of the Mediterranean climate follows, which is one with rainfall three times more abundant in the cold months than in the warm months (Köppen, 1900). In fact, in the Mediterranean region, the cumulated rainfall in the period between September and May accounts for more than the $80 \%$ of the total annual precipitation (Hurrell, 1995). During this period the weather systems, originating over the Atlantic Ocean, are funnelled between the Iceland low and the Azores high and carried towards Europe by a relatively strong westerly flow. The variability of the stormtracks in the Euro-Atlantic region has been analyzed by Trigo (2006), using a 6-h geopotential database for the period 1958-2000. This analysis shows that the main cyclogenesis maxima occur over the North Atlantic,

Published by Copernicus Publications on behalf of the European Geosciences Union. 
east of North America and Greenland, with a tendency to a northward shift of the stormtrack in the last decades, while over the western Mediterranean Sea and the Caspian Sea the cyclones are generally less intense than those over Atlantic. In winter, the main cyclogenetic areas in the Mediterranean Sea are the Gulf of Genoa, the Aegean Sea and the Black Sea, where the low-level baroclinicity is enhanced by the interaction between the synoptic systems originating over the Atlantic and the orography, favoring the development of subsynoptic perturbations (Trigo et al., 2002). In spring, the perturbations on the lee of the Atlas and over the Middle East are mainly thermally induced (Trigo et al., 1999). In summer, when the strong westerly flow moves polewards, the temperature gradients and the winds over South Europe are weak; this is because the eastern Mediterranean (EM) is under the ridge generated by the Indian monsoon (Rodwell and Hoskins, 1996) and the western Mediterranean (WM) is under the influence of the Saharan high, displaced northwards by the West African monsoon (Chen, 2005). Then the Mediterranean becomes rather dry, and rainfall originates in sporadic localized convective systems with scarce total accumulation (HMSO, 1962; Brody and Nestor, 1980; Reale et al., 2001).

The variability of the Mediterranean climate results from a combination of a number of parameters ranging from the planetary scale down to the subsynoptic scale. During the cold season, which is also the Mediterranean rainy season, European climate variability is dominated by midlatitude atmospheric large scale modes (Trigo et al., 2006). The main modes influencing the climate over Europe are the North Atlantic Oscillation (NAO) (van Loon and Rogers, 1978; Wallace and Gutzler, 1981), the Eastern Atlantic/Western Russia pattern (EA/WRUS; called EU-2 by Barnston and Livezey, 1987), and the Scandinavian pattern (SCAND; called EU-1 by Barnston and Livezey, 1987). The EA/WRUS mode has a 3-centre east-west pattern, with one centre of action close to the British islands, one in northeast China, and one centre of action with an opposite sign near the Caspian sea. This mode, prominent from September to May, is positively correlated with the winter precipitation in the Middle East, Turkey and the Black Sea, and negatively correlated with the precipitation in France and central Europe (Xoplaki, 2002). The SCAND mode is characterized by a strong centre of action in the Arctic Sea, north of the Scandinavian peninsula. This mode is prominent from August to May, and it is positively correlated with the winter precipitation in South Europe, and negatively correlated with the precipitation over and east of the Black Sea (Xoplaki, 2002). However, it is generally accepted that, during the cold season, the rainfall distribution between North and South Europe is mainly determined by the polarity of the NAO index. This index, characterized by the simultaneous fluctuations of the Iceland low and Azores high (Walker, 1924), is correlated positively with rainfall in North Europe and negatively with the rainfall in South Europe (Marshall et al., 2001a). The time spectrum of the NAO index spans from weeks to decades and multidecades (Grossmann and Klotzbach, 2009), with enhanced power in some frequency bands although this power is not sufficiently large to be really significant (Deser and Blackmon, 1993; Wunsch, 1999; Stephenson et al., 2000; Hurrell and Deser, 2010). This reddish spectrum, with preferred periods longer than a month, is determined by the lifetime of the sea surface temperature differences, by the lifetime of the continental snow cover, and by the slow fluctuations of the sea-ice cover (Rodwell et al., 1999; Marshall et al., 2001b; Ogi et al., 2003, 2005).

The relatively strong westerly flow which separates the Iceland low from the Azores high in the lower troposphere, becomes a jet in the higher troposphere. Actually, in the Euro-Atlantic region there are two branches of the jetstream, the African jet and the Atlantic jet (Branstator, 2002). The African jet is a branch of the Hadley-driven extratropical jet, which spans zonally from the west coast of North Africa to the Arabic peninsula and beyond it. This jet flows over the coast of North Africa at about $25^{\circ} \mathrm{N}$, changing latitude inphase with the fluctuations of the thermal gradient between Africa and South Europe. The Atlantic jet, which is maintained by the thermal contrast between the warm ocean and the polar region, crosses the North Atlantic with a northeasterly tilt at a latitude of about $45^{\circ} \mathrm{N}$ (Bryson, 1994). When the ocean is almost uniformly warm and the east coast of North America is cold, then the Atlantic jet is strong and the NAO index is positive (Bjerknes, 1964; Bryson, 1994; Kushnir, 1994; Enfield et al., 2001). Detailing, this jet is modulated by the fluctuations of the NAO polarity, i.e., when the NAO index is positive, this jet becomes stronger, its northeasterly tilt increases, and its exit region migrates northwards; when the NAO index is negative, this jet becomes weaker, its northeasterly tilt decreases, and its exit region migrates southwards (Hurrell et al., 2003; Vallis and Gerber, 2008).

Even if a comprehensive simple theory for the nonlinear interaction between the large scale flow and the weather systems is still absent (Hoskins et al., 1983), observational evidence shows that the weather systems are carried towards Europe by the southwesterly air-flow over the ocean, with the stormtrack roughly overlapping with the exit region of the Atlantic jet (Rodwell et al., 1999). In addition, the vertically integrated water vapor flux, which supplies moisture to these systems, approximately follows the same pattern of the Atlantic jet, i.e., when the NAO is positive (negative), the vertically integrated water vapor flux points towards North Europe (South Europe) (Hurrell, 1995). An analysis done by Ruti et al. (2006) using NCEP-NCAR reanalysis and ECMWF data strengthens the hypothesis that the jets can catalyze the atmospheric perturbations at low frequency because of their persistency, determined by large scale thermal contrasts by far exceeding the lifetime of the weather perturbations.

Given these observational facts, we focus our study on the rainfall distribution during the Mediterranean rainy season 
Table 1. Variance explained by the NAO (Hurrel et al., 2003) and by the 1 st PC of the $300 \mathrm{hPa}$ zonal wind (PC1) over North Atlantic; correlation between the NAO and the $\mathrm{PC} 1$ time-series.

\begin{tabular}{lccc}
\hline & $\begin{array}{c}\text { NAO } \\
\text { explained } \\
\text { variance }\end{array}$ & $\begin{array}{c}\text { U300 PC1 } \\
\text { explained } \\
\text { variance }\end{array}$ & $\begin{array}{c}\text { PC1-NAO } \\
\text { Correlation }\end{array}$ \\
\hline SON & 0.23 & 0.32 & 0.43 \\
DJF & 0.37 & 0.45 & 0.72 \\
MAM & 0.30 & 0.36 & 0.73 \\
\hline
\end{tabular}

Table 2. Summary of the SVD applied to $300 \mathrm{hPa}$ zonal wind and stormtrack and precipitation, in fall, winter and spring: 1st mode (SVD1) squared covariance fraction (SCF) and correlation between the expansion coefficients time-series (ECs).

\begin{tabular}{llcllc}
\hline & \multicolumn{2}{l}{$\mathrm{U} 300$-stormtrack SVD1 } & & \multicolumn{2}{c}{ U300-precipitation SVD1 } \\
\cline { 2 - 3 } \cline { 5 - 6 } & SCF & $R(\mathrm{ECs})$ & & SCF & $R(\mathrm{ECs})$ \\
\hline SON & 0.47 & 0.90 & & 0.38 & 0.90 \\
DJF & 0.53 & 0.94 & & 0.45 & 0.83 \\
MAM & 0.44 & 0.93 & & 0.38 & 0.82 \\
\hline
\end{tabular}

(September to May), showing that the seasonal rainfall distribution is strongly correlated to the configuration of the jets in the Euro-Atlantic region. Specifically, it will be shown that these jets exert their control on storm distribution through almost meridional thermal and vorticity advections present in their respective cross-jet circulations. Data and methods are described in Sect. 2; in Sect. 3 we describe the relationship between the NAO index and the stormtracks guided by the Atlantic jet; the dynamical features of the cross-jet circulation are detailed in Sect. 4; the related seasonal rainfall distribution is shown in Sect. 5; the rainfall anomalies induced by the jetstream variability are shown in Sect. 6; finally the conclusions are drawn in Sect. 7.

\section{Data and methods}

The rainfall analysis is performed within $10^{\circ} \mathrm{W}-40^{\circ} \mathrm{E}$, $30^{\circ} \mathrm{N}-50^{\circ} \mathrm{N}$; the region enclosed by these boundaries includes the entire Mediterranean sea and its surrounding mountain ranges. The rainfall data were taken from the CPC Merged Analysis of Precipitation (CMAP) (Xie and Arkin, 1997). These data are a combination of the raingauge observations with the satellite-estimated precipitations, and they are available on a global domain at $2.5^{\circ}$ resolution.

The atmospheric dynamical features are analyzed within $80^{\circ} \mathrm{W}-60^{\circ} \mathrm{E}, 20^{\circ} \mathrm{N}-70^{\circ} \mathrm{N}$. This domain is larger than the domain where the rainfall is analyzed in order to enclose also that portion of the Euro-Atlantic region where there are

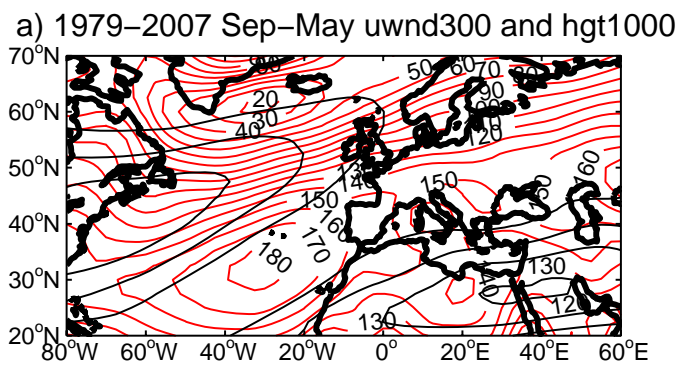

b) 1979-2007 Sep-May uwnd300 and stormtrack

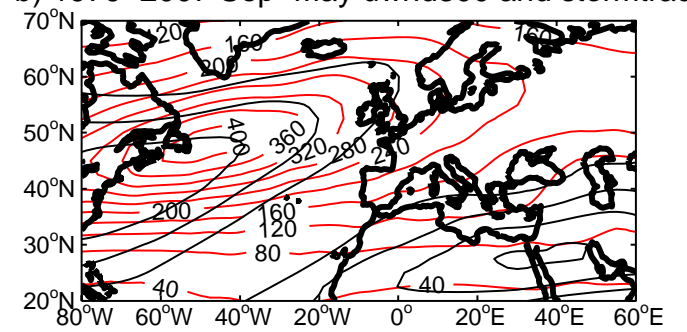

c) 1979-2007 Sep-May U300 PC1 | exp.var $=0.38$

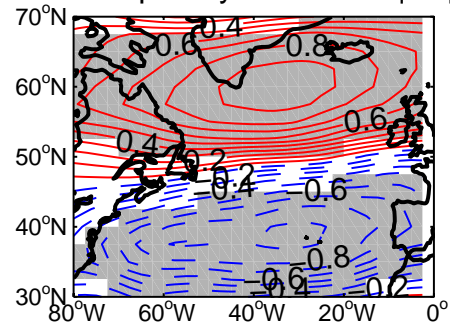

d) 1979-2007 Sep-May NAO(bars)-PC1(line) | R $=0.62$

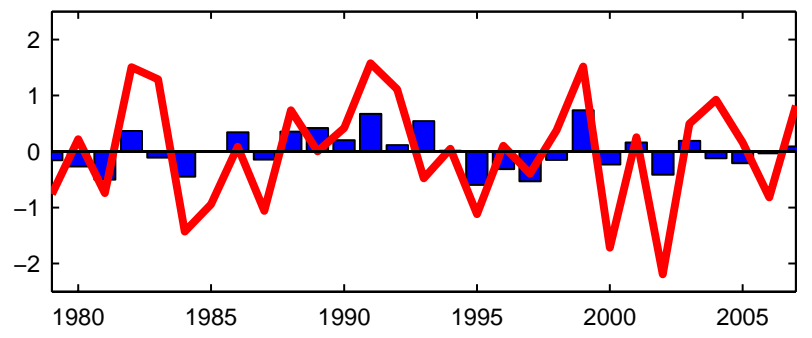

Fig. 1. September to May climatology: (a) geopotential at $1000 \mathrm{hPa}$ (m) (red contours); (b) stormtrack at $300 \mathrm{hPa}\left(\mathrm{m}^{2} \mathrm{~s}^{-2}\right.$ ) (red contours); (a) and (b) the zonal wind at $300 \mathrm{hPa}$ (black contours, $5 \mathrm{~m} \mathrm{~s}^{-1}$ interval beginning at $15 \mathrm{~m} \mathrm{~s}^{-1}$ ). September to May interannual variability: (c) 1st PC of the $300 \mathrm{hPa}$ zonal wind (PC1) in homogeneous correlation maps (positive values in red, negative values dashed in blue, $95 \%$ significance shaded in gray); (d) PC1 time-series (red line) and NAO index (blue bars).

the exit region of the Atlantic jet and the entry region of the African jet. The horizontal wind components, the vertical velocity ( $\omega$, in pressure units), the geopotential height and the potential temperature between 1000 and $100 \mathrm{hPa}$ are extracted from the NCEP-DOE Reanalysis 2 dataset (R-2; Kanamitsu et al., 2002). The R-2 dataset is derived from the NCEP-NCAR Reanalysis, which incorporates satellite observations, model simulations and in situ data. These data 

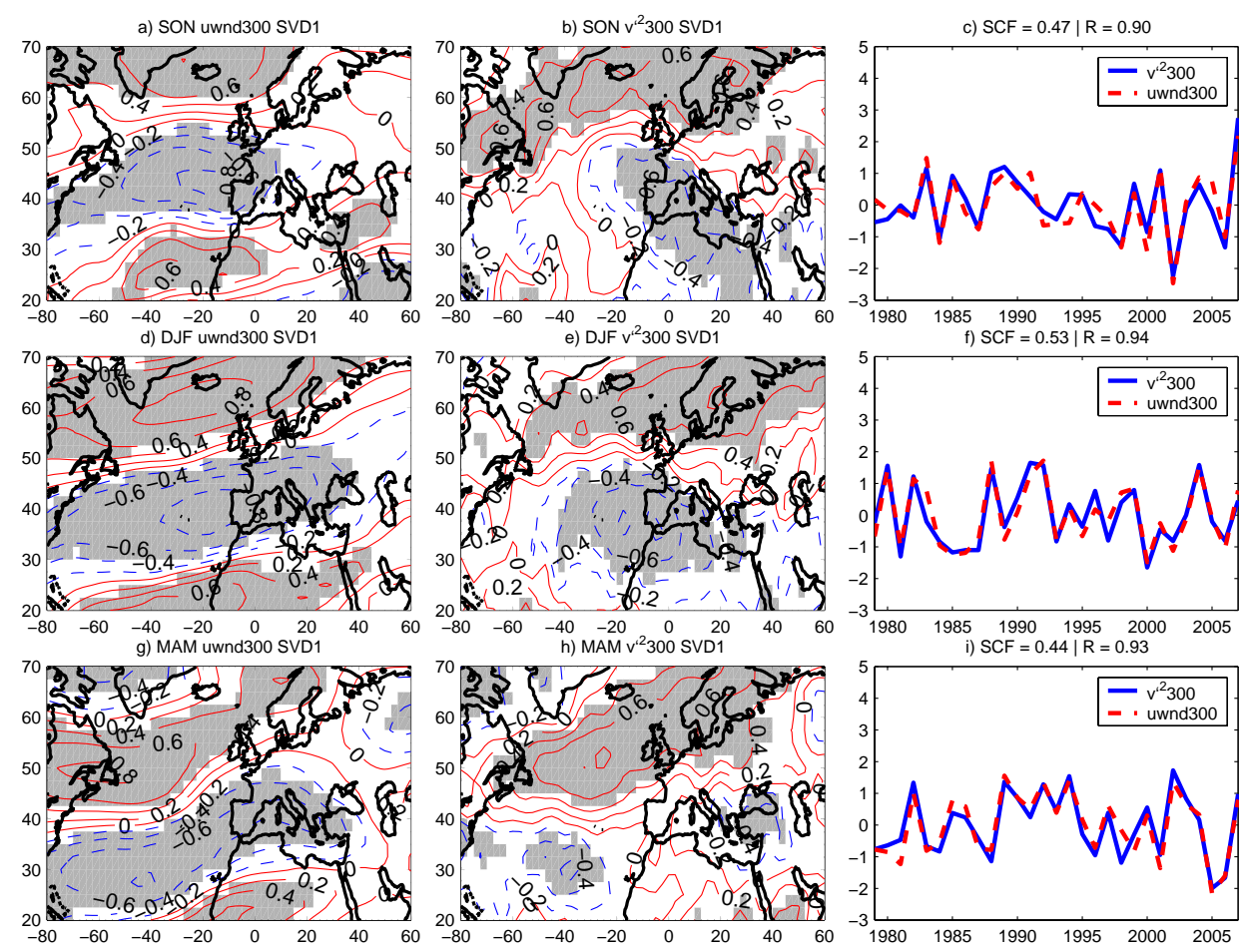

Fig. 2. Heterogeneous correlation maps of the 1st SVD mode (SVD1) between zonal wind (a, d, g) and stormtrack (b, e, h) at $300 \mathrm{hPa}$, and related expansion coefficients (c, $\mathbf{f}, \mathbf{i})$ : in fall (upper panels), in winter (middle panels) and in spring (bottom panels). Positive values in red, negative values dashed in blue, $95 \%$ significance shaded in gray.
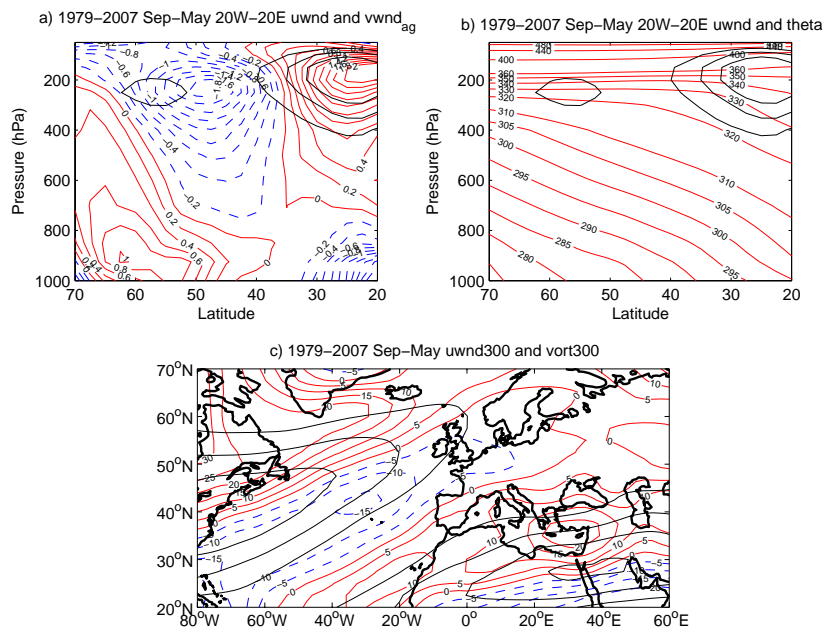

Fig. 3. September to May climatology. Meridional cross section zonally averaged between $20^{\circ} \mathrm{W}$ and $20^{\circ} \mathrm{E}$ : (a) ageostrophic meridional wind $\mathrm{m} \mathrm{s}^{-1}$ (positive values in red, negative values dashed in blue); (b) potential temperature (K) (red contours); the zonal wind is superimposed in black contours $\left(5 \mathrm{~m} \mathrm{~s}^{-1}\right.$ interval beginning at $15 \mathrm{~m} \mathrm{~s}^{-1}$ ); (c) $300 \mathrm{hPa}$ zonal wind $\mathrm{m} \mathrm{s}^{-1}$ (black contours, $5 \mathrm{~m} \mathrm{~s}^{-1}$ interval beginning at $15 \mathrm{~m} \mathrm{~s}^{-1}$ ) and vorticity $\left(10^{-6} \mathrm{~s}^{-1}\right)$ (positive values in red, negative values dashed in blue). have a horizontal resolution of $2.5^{\circ}$ and are available in a number of vertical levels, given in pressure or sigma coordinates.

Hereafter, the jet is identified with that region where the zonal wind exceeds $15 \mathrm{~m} \mathrm{~s}^{-1}$ at $300 \mathrm{hPa}$ (Branstator, 2002). The storm activity is evaluated using the variance of the meridional wind component at $300 \mathrm{hPa}$ (Harnik and Chang, 2003),

$v^{\prime}=\frac{1}{N} \sum_{n=1}^{N}\left(v_{n+1}-v_{n}\right)^{2}$,

where $v_{n}$ is the meridional wind on the $n$-th day, and $N$ is the number of days through which the storm activity is evaluated. The NAO index is computed using the monthly data of the NOAA Climate Prediction Center (http://www.cpc.ncep. noaa.gov/).

Our study refers to the period 1979-2007 and we apply the Principal Component Analysis (PCA) and the Singular Value Decomposition (SVD) analysis (von Storch and Zwiers, 1999). The PCA is used for identifying the main mode of a field, while the SVD is used for computing the covariance between two fields. The data are standardized with the linear trend removed, and with the interannual variability retained. The related dynamical features are analyzed using composite analysis. Finally, having verified that the 
1st mode explains a large fraction of the variance and of the covariance, the results shown hereafter refer to this mode.

\section{NAO and the Atlantic jet}

During the rainy season, the projection on the surface of the Atlantic jet overlaps with the pronounced pressure gradient located between the Icelandic low pressure and the Azores high pressure (Fig. 1a), with a concentration of storm activity in the exit region of this jet (Fig. 1b). The anomaly pattern of the 1st PC of the $300 \mathrm{hPa}$ zonal wind (PC1), computed for the North Atlantic in September-May (Fig. 1c), strongly resembles the north-south pressure dipole of the wintertime NAO (Hurrell et al., 2003). The positive interannual relationship between the zonal wind and the NAO is clearly seen in the correlation between the PC1 time-series and the NAO index ( $r=0.62$, Fig. 1d). This fact suggests that a northward (southward) displacement of the jet is related to a positive (negative) value of the NAO index. The robustness of the jet-NAO relationship is confirmed by the fact that the PC1 explained variance and the correlation between the PC1 time-series and the NAO index are higher in winter and spring than in fall (see Table 1 and also Hurrell et al., 2003). In addition, the results from the SVD analysis show that the jets are well correlated with the storm activity (Wallace et al., 1988). Detailing, in fall an intensification of the jet over North Europe with a weakening of the jet over southwestern Europe is accompanied by an intensification of the storminess over North Europe and by a weakening of the storminess over southwestern Europe (Fig. 2a and b), with the related Expansion Coefficients (ECs) shown in Fig. 2c. In winter, the pattern is as in fall, but with a stronger coupling (Fig. 2d, e and f). In spring, an intensification of the jet over North Europe, accompanied by a weakening of the jet over the Tropical Atlantic results in an intensification of the storminess over North Europe and in a weakening of the storminess over southeastern Europe (Fig. 2g, h and i). The Squared Covariance Fraction (SCF) and the correlations between the ECs time-series associated to the SVD are summarized in Table 2.

\section{Cross-jet circulations}

The exit and entrance regions of a jet are characterized by cross-jet circulations; a schematic picture of these circulations, and of the related horizontal advections, is shown by Uccellini and Kocin (1987) in their Fig. 3: to the south of the entrance region of a jet, the thermal advection lowers the available potential energy, making the air more stable and inhibiting the formation of weather perturbations, whereas the thermal advection in the exit region of a jet increases the potential energy, making it available for the weather system development. In the specific case of the two jets in the

\section{Upper Troposphere}
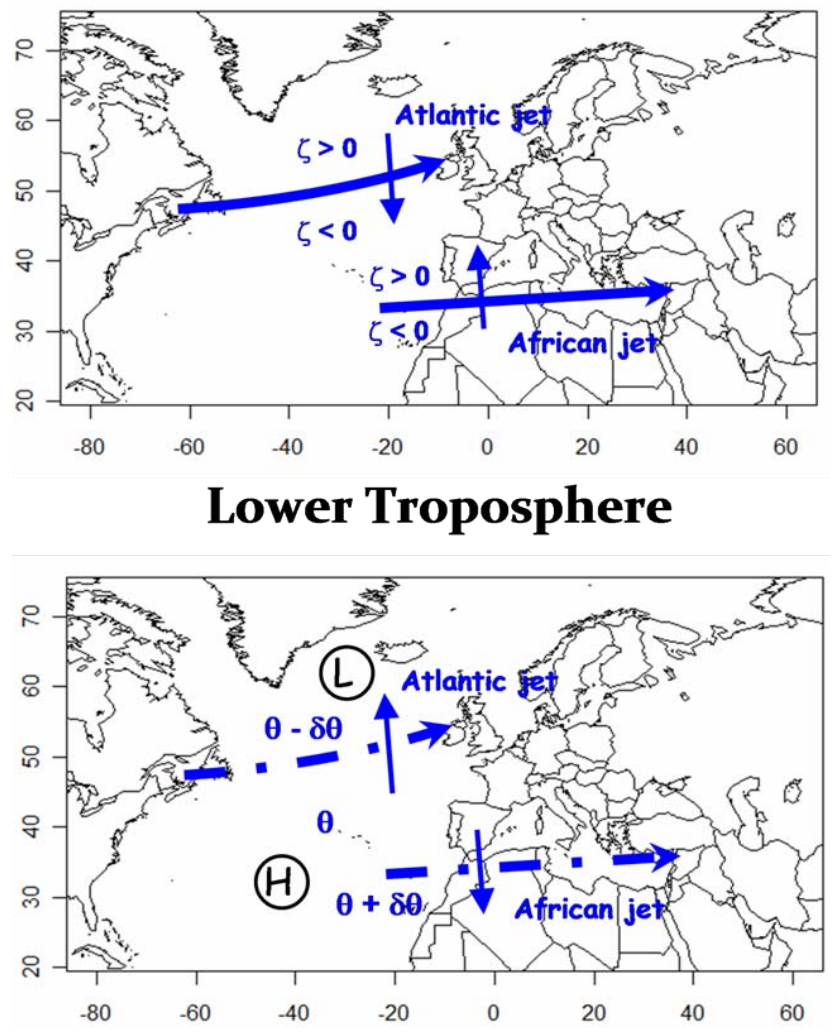

Fig. 4. Conceptual picture of the vorticity and thermal advections driven by the cross-jet circulations in the exit region of the Atlantic jet and in the entrance region of the African jet.

Euro-Atlantic region, the vertical cross section of the meridional ageostrophic wind, zonally averaged through $20^{\circ} \mathrm{W}-$ $20^{\circ} \mathrm{E}$, shows that the cross-jet circulation contributes to the divergence, with upward motion, in the mid and upper troposphere in the exit region of the Atlantic jet, and to the lower tropospheric divergence with subsiding motion, below the entrance region of the African jet (Fig. 3a). The divergent ageostrophic wind components have been computed by subtracting from the wind vector the geostrophic contribution,

$\boldsymbol{u}_{\mathrm{ag}}=\boldsymbol{u}-\boldsymbol{u}_{\mathrm{g}}$, with $\boldsymbol{u}_{\mathrm{g}}=-\frac{1}{\rho f} \boldsymbol{k} \times \nabla p$,

where $f$ is the Coriolis parameter, $\rho$ is the air density, and $\boldsymbol{k}$ is the vertical unit vector. In the lower troposphere, below the exit region of the Atlantic jet, the northwards flow in the midlatitudes increases the baroclinicity, generating Convective Available Potential Energy (CAPE), while the southwards flow below the entrance region of the African jet lowers the baroclinicity and the CAPE (Fig. 3a and b). The CAPE tendency is computed using the horizontal thermal advection (Eshel and Farrell, 2001), 

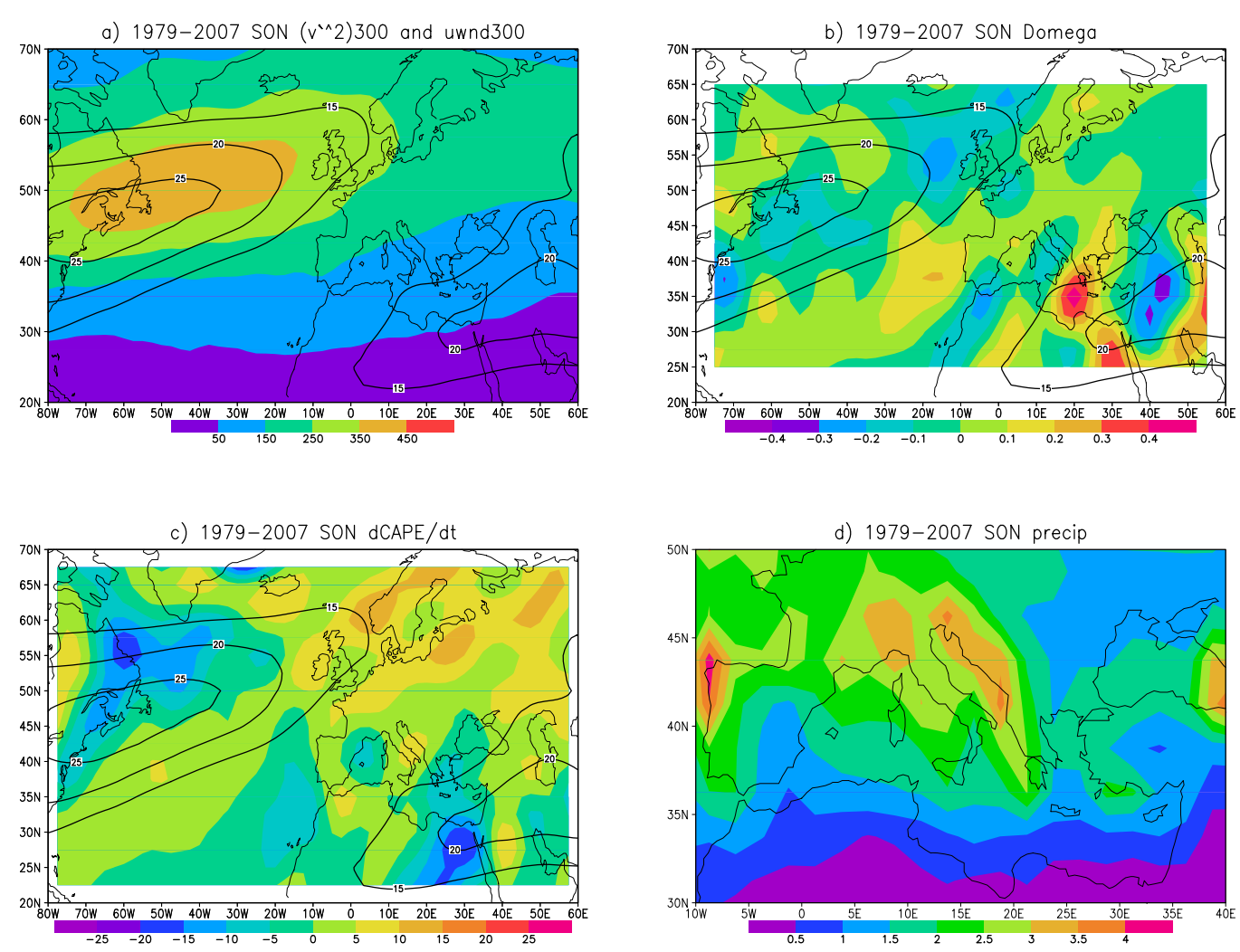

Fig. 5. Fall climatology: (a) stormtrack $\left(\mathrm{m}^{2} \mathrm{~s}^{-2}\right)$; (b) vertical velocity increment in the upper troposphere $\left(\mathrm{hPa} \mathrm{s} \mathrm{s}^{-1}\right)$; (c) CAPE tendency in the lower troposphere $\left(100 \mathrm{~J} \mathrm{Kg}^{-1} \mathrm{~s}^{-1}\right)$; the zonal wind at $300 \mathrm{hPa}$ is superimposed in black contours $\left(5 \mathrm{~m} \mathrm{~s}^{-1}\right.$ interval beginning at $\left.15 \mathrm{~m} \mathrm{~s}^{-1}\right)$; (d) rainfall $\left(\mathrm{mm} \mathrm{day}^{-1}\right)$.
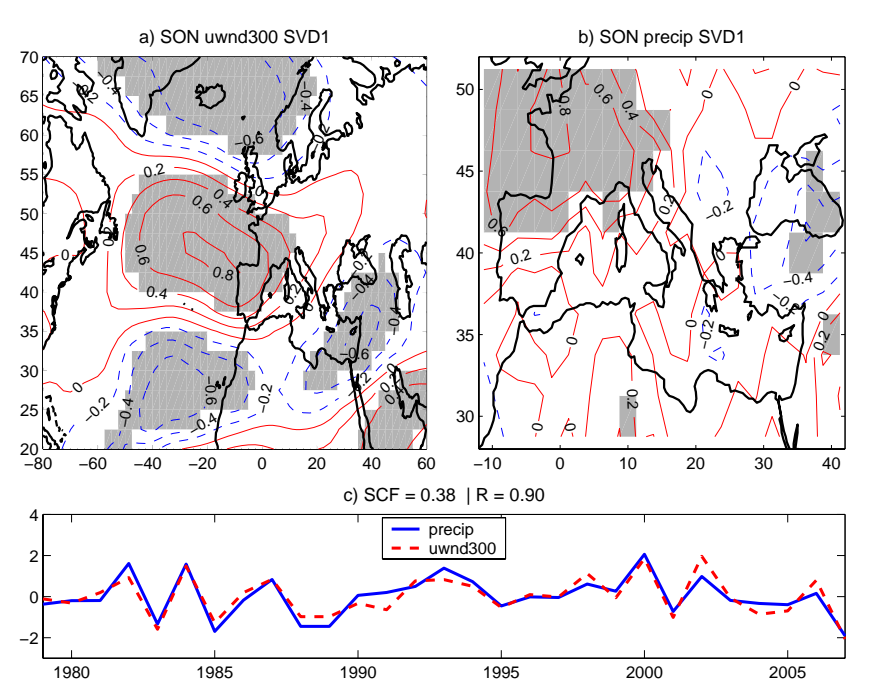

Fig. 6. Heterogeneous correlation maps of the 1st SVD mode (SVD1) between $300 \mathrm{hPa}$ zonal wind (a) and precipitation (b) and related expansion coefficients (c), in fall. Positive values in red, negative values dashed in blue, $95 \%$ significance shaded in gray.
$\partial_{t}(\mathrm{CAPE})=\int_{z 1}^{z 2} w N^{2} d z \approx-\frac{1}{\rho \theta} \int_{700}^{925} \boldsymbol{u} \cdot \nabla_{p} \theta d p$

where $N^{2}$ is the Brunt-Väisäla frequency, $w$ the vertical velocity, $\rho$ is the air density, and $\theta$ is the potential temperature. In this approximation, the flow is assumed adiabatic, $D_{t}$ $\theta=0$, with the thermal vertical advection in balance with the horizontal thermal advection and with the temperature tendency neglected. While the sign of the advections is correct in this approximation, the intensity of the advections is underestimated by this approximation when the development of the perturbations is strengthened by the diabatic interaction between the cold air masses and the warmer Mediterranean Sea (Ziv et al., 2010). In the upper troposphere, the horizontal wind shear in the exit region of the Atlantic jet and in the entrance region of the African jet is very large (Fig. 3c); the southwards horizontal vorticity advection enhances the upwards motion in the exit region of the Atlantic jet, whereas the northwards vorticity advection favors the subsiding motion in the entrance region of the African jet; in the upper troposphere the changes of the vertical velocity are induced by these advections, 

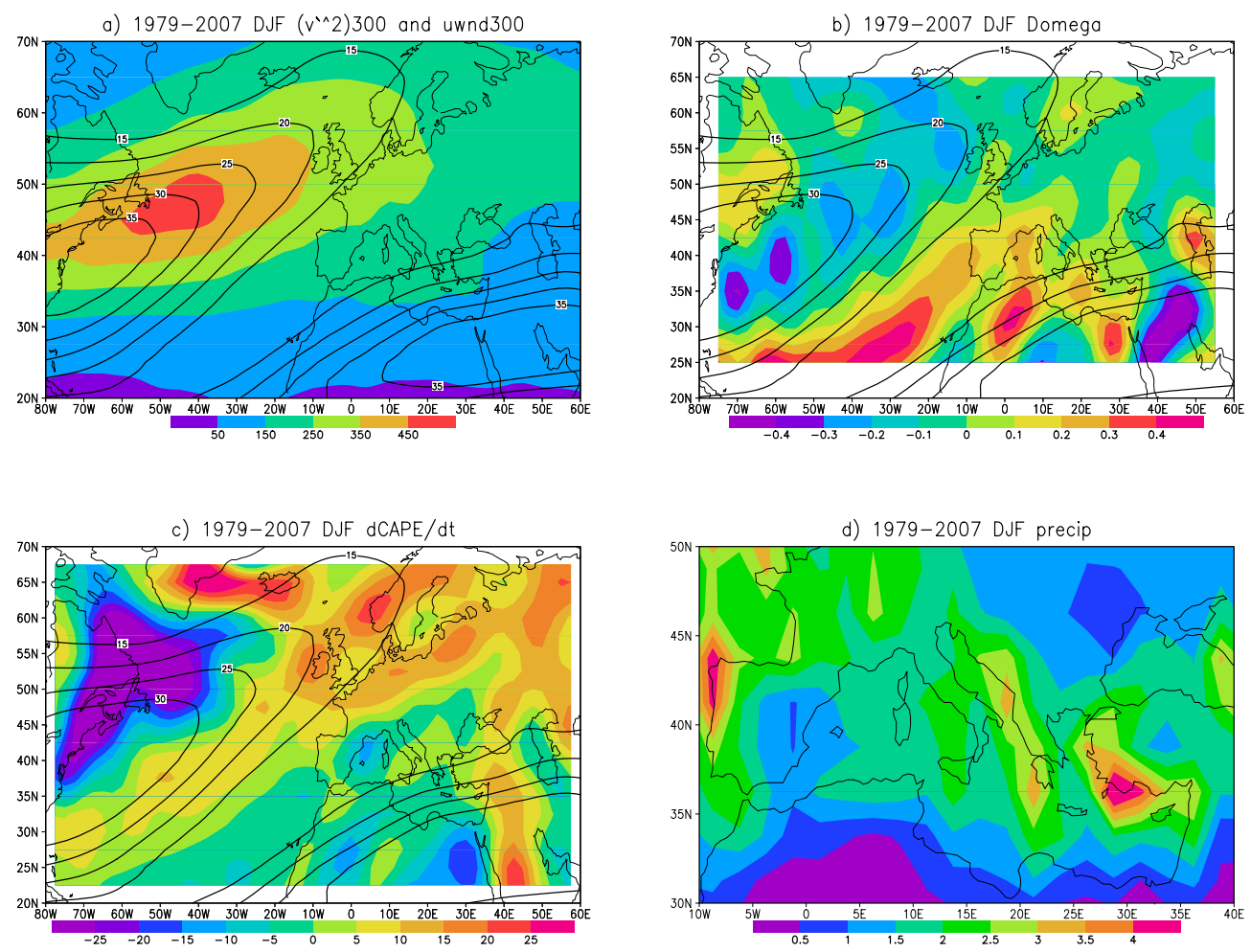

Fig. 7. Same as Fig. 5, but for winter.
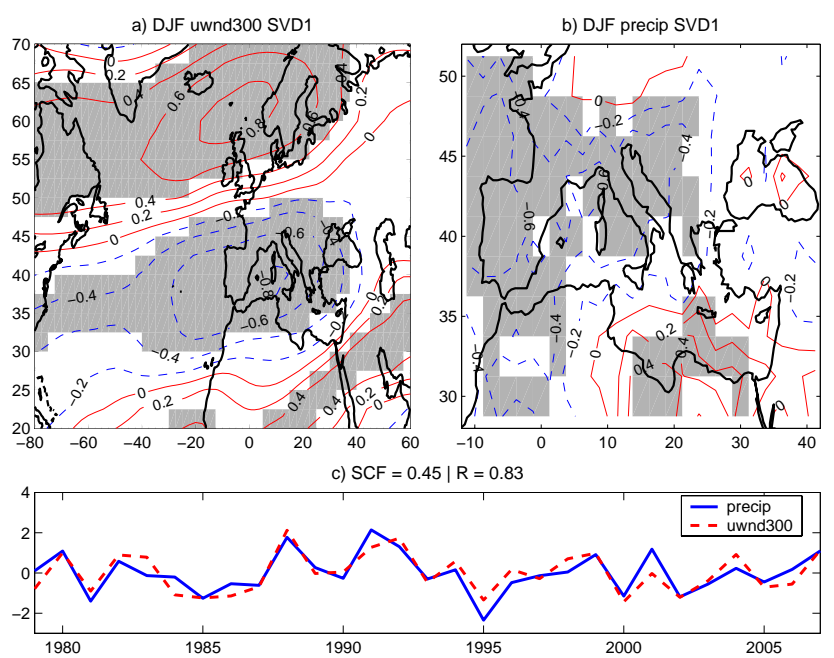

vortex stretching in frictionless large scale flows (Eq. 4.22 in Holton, 1992), the second equation is the conservation of the potential vorticity, with the vorticity tendency neglected. A schematic picture of the cross-jet circulation in the Euro-Atlantic region is shown in Fig. 4. In Fig. 4a (upper troposphere), the cross-jet circulation advects vorticity southwards in the exit region of the Atlantic jet and northwards in the entrance region of the African jet whereas, in the lower troposphere (Fig. 4b), the thermal advection is northwards in the exit region of the Atlantic jet and southwards in the entrance region of the African jet.

The storm pattern eastwards of the exit region of the Atlantic jet can be described using the schematic picture shown by Hoskins et al. (1983) in their Fig. 13: the eddy activity generated in the lower troposphere propagates upwards and eastwards, where this activity strengthens the barotropic wind by weakening the wind shear. Towards the exit region of the jet, where the barotropic flow weakens and spreads horizontally, the eddy activity also spreads. The storms in the northeasterly side of the jet are deflected towards North Europe, whereas the storms in the southeasterly side of the jet are deflected towards the Mediterranean region.

Summarizing, the thermal advection in the exit (entrance) region of the Atlantic (African) jet produces an accumulation (a depletion) of the CAPE in the lower troposphere, in conjunction with an upward (downward) motion in the upper troposphere. I.e., the cross-jet circulation in the exit region

where $(\zeta+f)$ is the absolute vorticity. The first equation reflects the change of the absolute vorticity due to the 

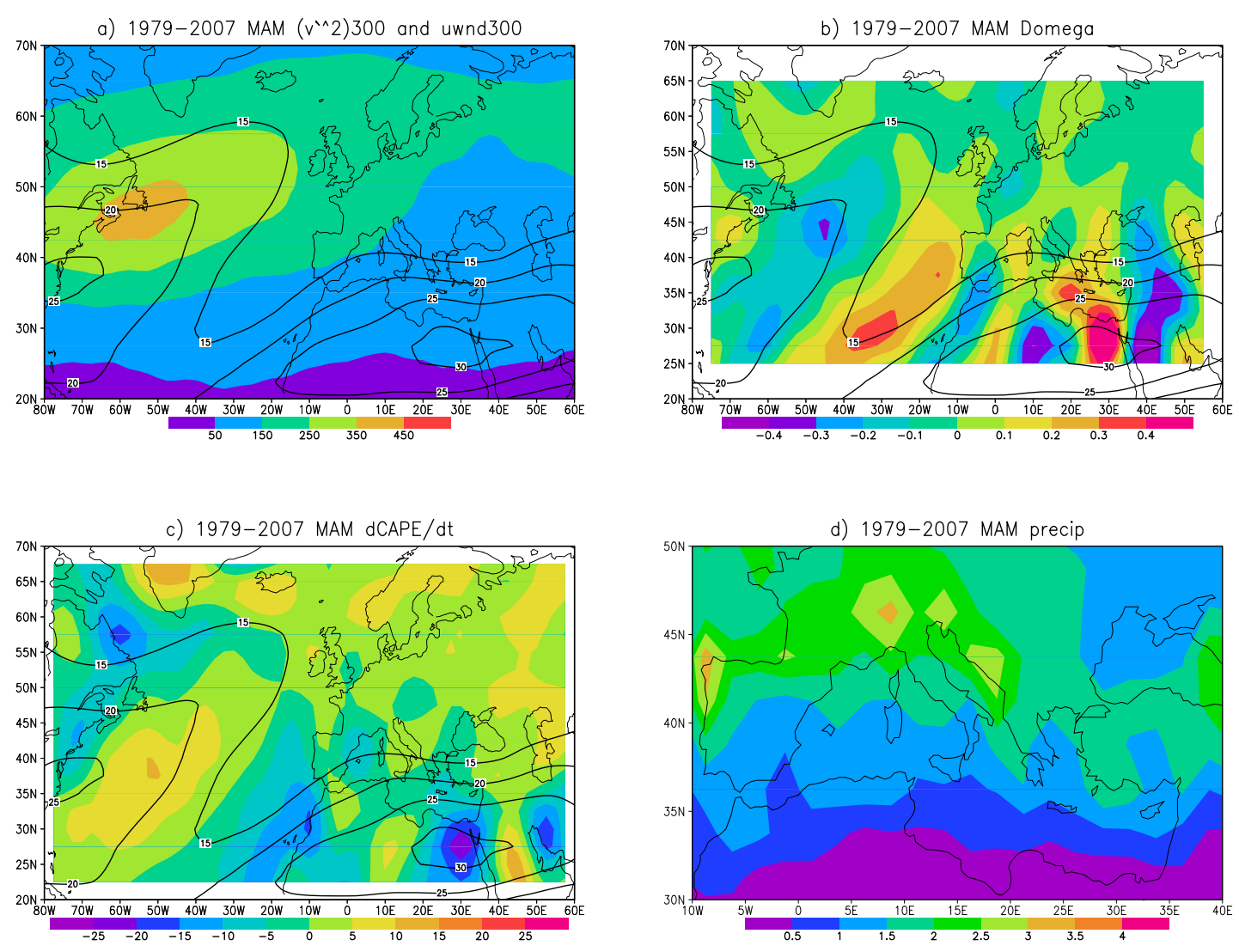

Fig. 9. Same as Fig. 5, but for spring.

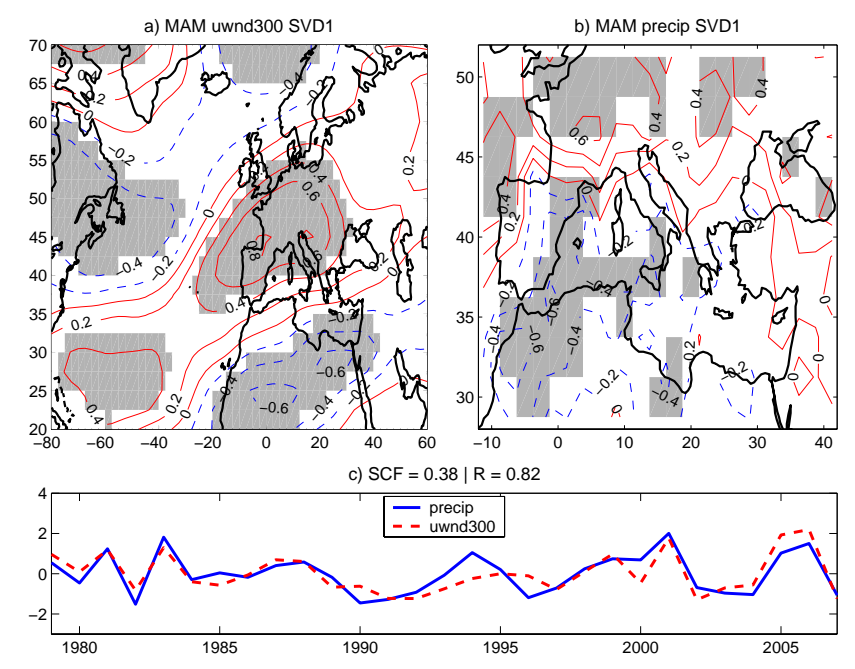

horizontal thermal and the vorticity advections can be found in Holton (1992), Rodwell and Hoskins (1996), and in Eshel and Farrell (2000).

\section{Seasonal rainfall distribution}

Having analyzed the dynamical aspect of the cross-jet circulations in the previous section, this section is devoted to the analysis of the seasonal precipitation patterns downstream of these circulations. In addition, the relationship between jetstream and rainfall variability is analyzed through the SVD of $300 \mathrm{hPa}$ zonal wind and precipitation, in order to highlight the role played by the jets.

\subsection{Fall}

Fig. 10. Same as Fig. 6, but for spring.

of the Atlantic jet favors the development of the weather perturbations, as shown by a concentration of storm activity in the exit region of the Atlantic jet, while the cross-jet circulation in the entrance region of the African jet hinders the formation of these perturbations by making the air more stable. Theoretical details on the vertical motions forced by

In fall, storm activity is concentrated in the exit region of the Atlantic jet, which becomes relatively strong because of the rapid cooling of the polar region after the summer, while the African jet is relatively weak because the southern Euro-Asiatic continent is still quite warm (Fig. 5a). With this jet configuration, the air rises over southwestern Europe and subsides over the EM (Fig. 5b); the CAPE increases in the lower troposphere along the southeastern edge of the Atlantic jet and decreases over the EM (Fig. 5c). Rainfall is 

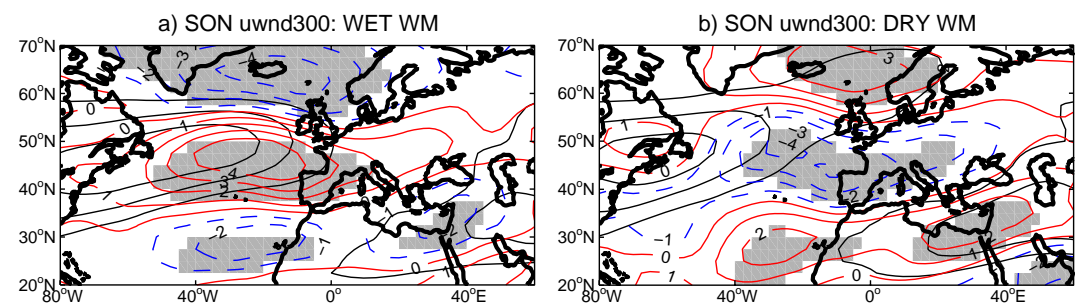

c) SON precip: WET WM
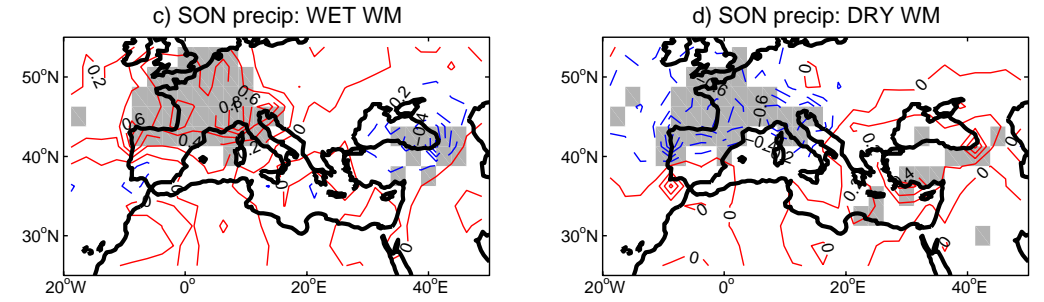

e) SON 20W-20E: WET WM

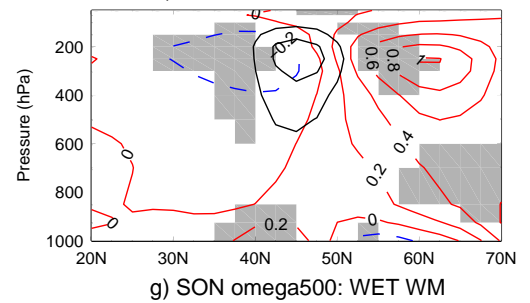

f) SON 20W-20E: DRY WM
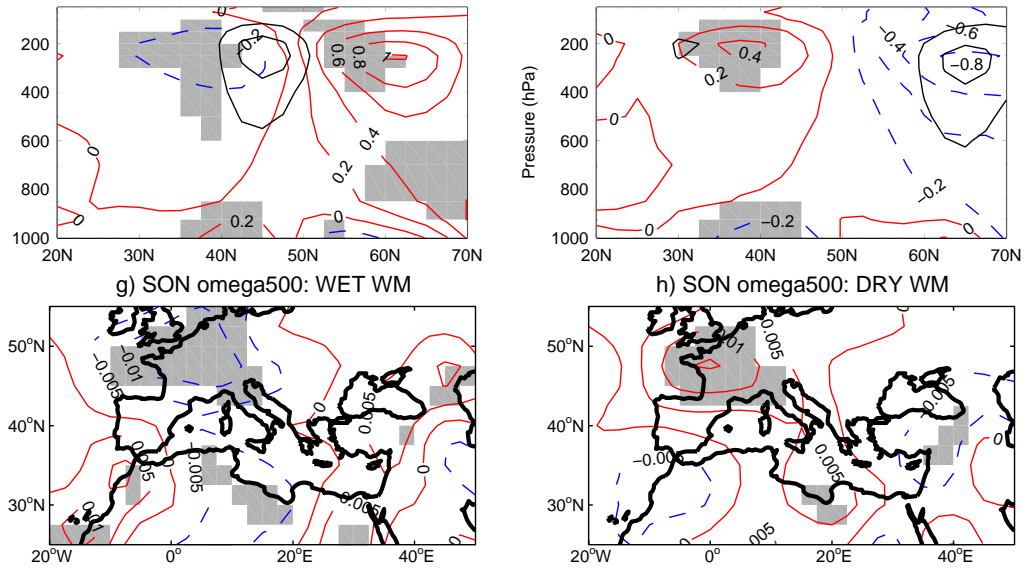

Fig. 11. Fall composite analysis: years when the WM was wetter than normal in the left panels; years when the WM was dryer than normal in the right panels; positive values in red, negative values dashed in blue, $95 \%$ significance shaded in gray. (a, b) $300 \mathrm{hPa}$ zonal wind mean (black contours, $5 \mathrm{~m} \mathrm{~s}^{-1}$ interval beginning at $15 \mathrm{~m} \mathrm{~s}^{-1}$ ) and its anomaly $\mathrm{m} \mathrm{s}^{-1}$; (c, d) rainfall anomaly (mm day ${ }^{-1}$ ); (e, f) meridional ageostrophic wind $\mathrm{ms}^{-1}$ and zonal wind (black contours, $2 \mathrm{~m} \mathrm{~s}^{-1}$ interval beginning at $2 \mathrm{~m} \mathrm{~s}^{-1}$ ) anomaly, vertical cross section zonally averaged between $20^{\circ} \mathrm{W}$ and $20^{\circ} \mathrm{E} ;(\mathbf{g}, \mathbf{h})$ vertical velocity anomaly $\left(\mathrm{Pa} \mathrm{s}^{-1}\right)$.

abundant over Iberia, Italy, and the Balkans, while the EM is relatively drier than the WM (Fig. 5d). This overall picture has the additional support of the SVD analysis, which shows that an intensification of the jet over southwestern Europe carries more rain to this region (Fig. 6).

\subsection{Winter}

In winter both jets are very intense, the Atlantic jet has a large northeasterly tilt, and its exit region reaches the Scandinavian Peninsula; the African jet reaches the Atlantic ocean, with its entrance placed well off the coast of West Africa. With this jet configuration, the storm activity is intense over northwestern Europe, while it is absent over the WM, because the African cross-jet circulation hinders the storm activity (Fig. 7a); in fact subsidence prevails over Iberia, while the uprising motions prevail over South Italy, the Balkans, and Turkey (Fig. 7b), the CAPE increases along the southern edge of the Atlantic jet and over the EM (Fig. 7c); rainfall is abundant over the Balkans and Turkey, while southeastern Iberia and the WM are relatively drier than the EM (Fig. 7d). In this case, the SVD analysis shows that an intensification of the westerly flow over North Europe, and a weakening of winds over South Europe, carries more rain to the southeastern Mediterranean basin, while the western and central Mediterranean are dryer than average (Fig. 8).

\subsection{Spring}

In spring, the Atlantic jet weakens and retreats over the middle of the Atlantic, also the African jet weakens, but it keeps its winter width and position. The storm activity weakens, and, even if the African cross-jet circulation weakens, it is still sufficiently efficient in inhibiting the storm activity over the WM (Fig. 9a). With this jet configuration, the upward motions are confined to the Italian Peninsula (Fig. 9b), where 


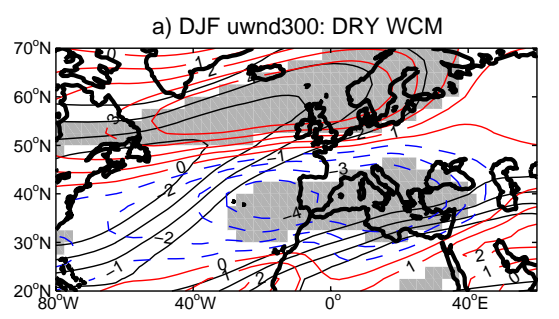

c) DJF precip: DRY WCM

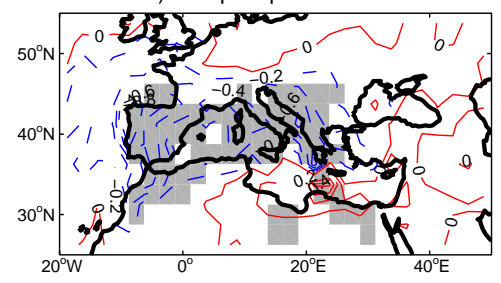

e) DJF 20W-20E: DRY WCM

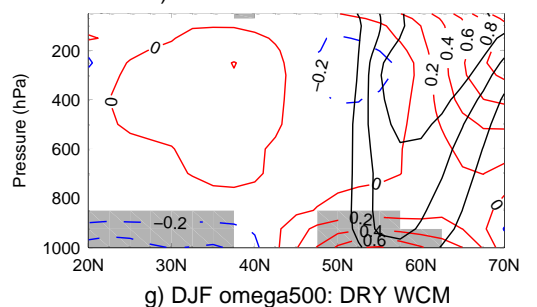

g) DJF omega500: DRY WCM

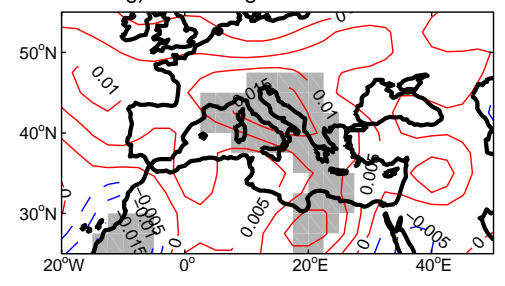

b) DJF uwnd300: WET WCM

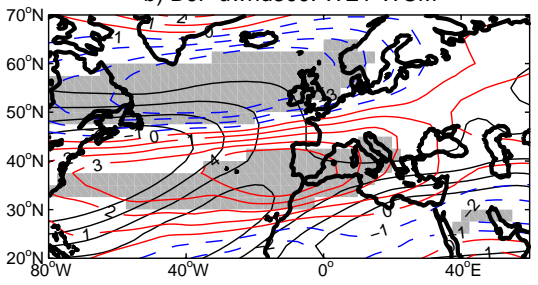

d) DJF precip: WET WCM

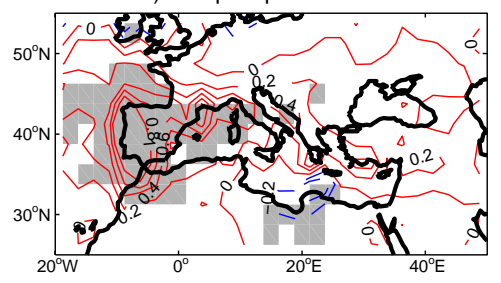

f) DJF 20W-20E: WET WCM
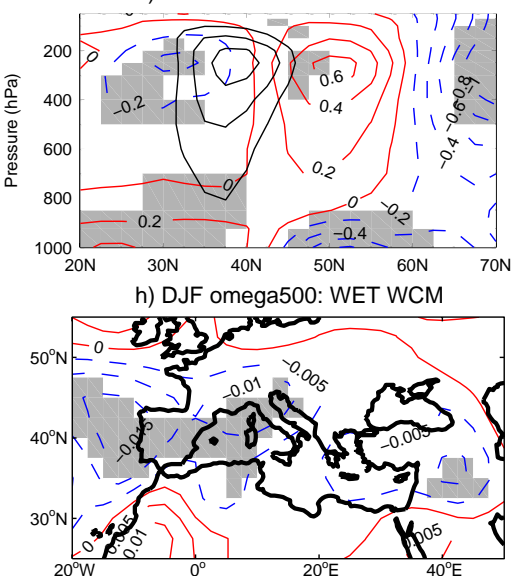

Fig. 12. Same as Fig. 11, but for winter: years when the western-central Mediterranean was drier than normal in the left panels; years when the western-central Mediterranean was wetter than normal in the right panels.

there is an increase of CAPE (Fig. 9c); the rainfall shows a maximum over the Alpine region and the Balkans (Fig. 9d). The SVD analysis shows that the weakening of the westerly flow over the ocean and over West Africa, with an intensification of these winds over western Europe, carries more rain to the northern Mediterranean region, while the southwestern Mediterranean is dryer than average (Fig. 10).

\section{Seasonal rainfall anomalies}

In this section the seasonal rainfall anomalies are analyzed in relation to the jetstream configuration, through a composite analysis. Based on the SVD analysis between the zonal wind and the precipitation, shown in the previous section, the composites are constructed using the highest (3rd) and the lowest (1st) tercile of the precipitation ECs time-series; the differences with the climatology are computed for the precipitation and the jetstream dynamical features.

\subsection{Fall}

In fall, when the rainfall is anomalously abundant in the $\mathrm{WM}$, the African jet is weak and in its easternmost position, whereas the Atlantic jet is almost zonal and in a rather southern position (Fig. 11a and c); the upper branch of the cross-jet circulation is stronger over Europe and weaker over North Africa (Fig. 11e), with reinforced rising motions over the WM (Fig. 11g). In these conditions the Black Sea is rather dry.

When the WM is drier than normal, the African jet is strong over North Africa, and the Atlantic jet has a large northeasterly tilt (Fig. 11b and d); the upper branch of the cross-jet circulation is stronger over Africa and weaker over Europe (Fig. 11f), with reinforced rising motions over the EM (Fig. 11h). In these conditions the EM is rather wet.

\subsection{Winter}

In winter as in fall, when rainfall is scarcer than normal in the western-central Mediterranean, the African jet is very 

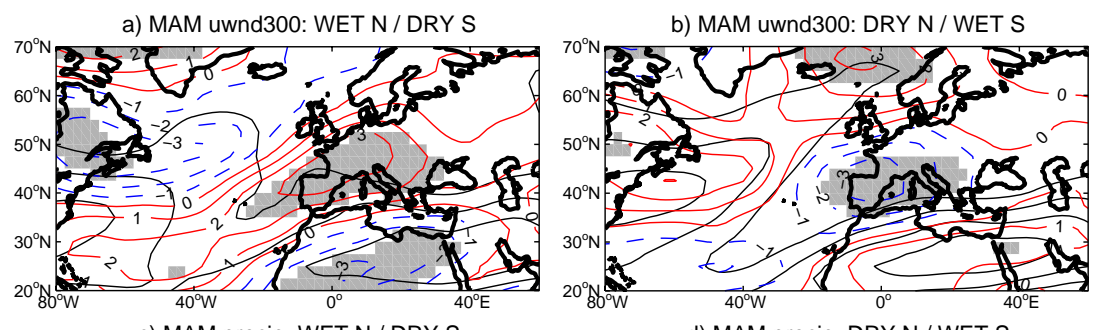

c) MAM precip: WET N / DRY S

d) MAM precip: DRY N / WET S
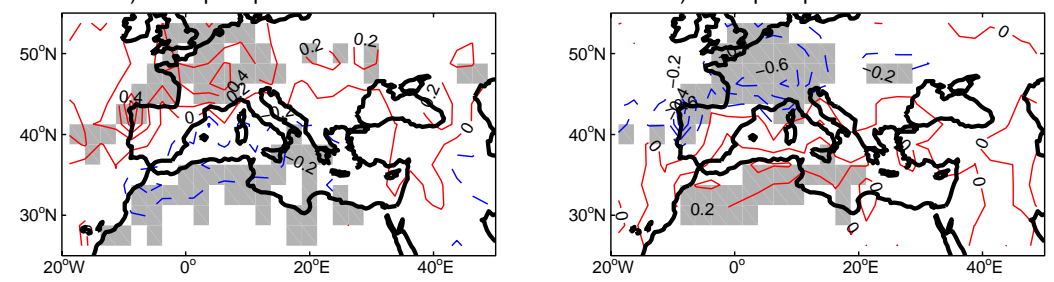

e) MAM 20W-20E: WET N / DRY S

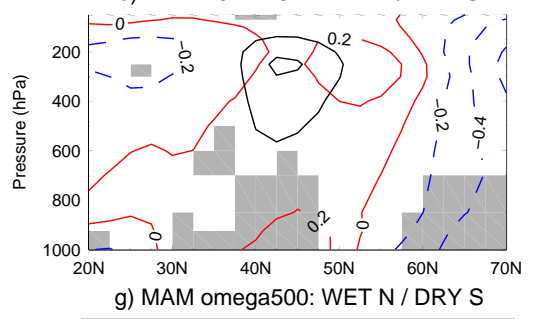

f) MAM 20W-20E: DRY N / WET S
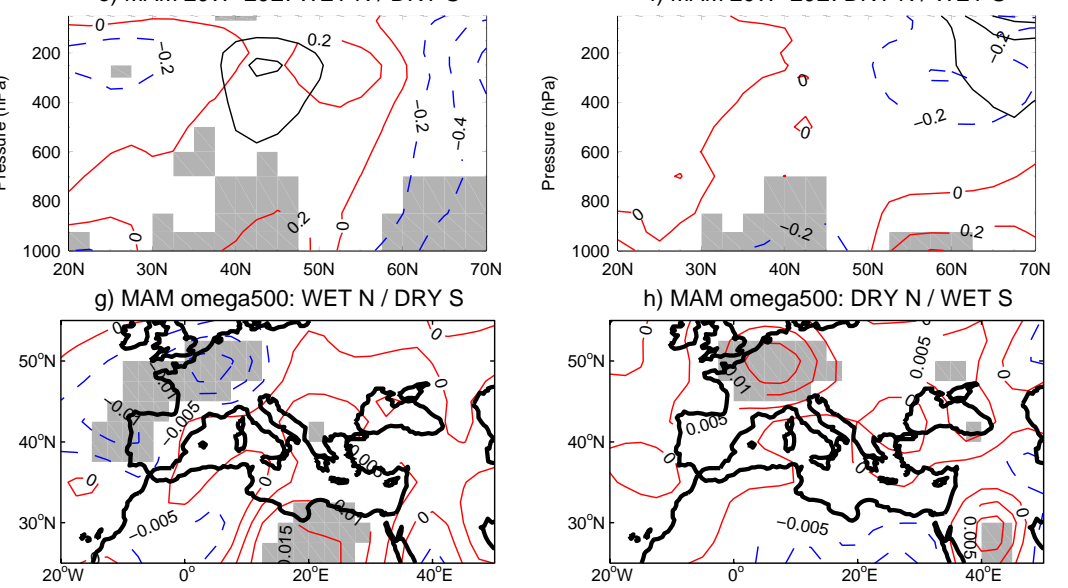

Fig. 13. Same as Fig. 11, but for spring: years when the northern Mediterranean was wetter and the southern Mediterranean was drier than normal in the left panels; years when the northern Mediterranean was drier and the southern Mediterranean was wetter than normal in the right panels.

strong, with its entrance region in the middle of the Tropical Atlantic. The Atlantic jet is also very strong, with a large northeasterly tilt (Fig. 12a and c). The upper branch of the cross-jet circulation is weaker over Europe and stronger over North Africa (Fig. 12e), with reinforced subsidence over the western-central Mediterranean (Fig. 12g). Under these conditions, rainfall is anomalously abundant in Northeast Africa.

When rainfall is anomalously abundant in the westerncentral Mediterranean, the African jet is weak and in a southern position, the Atlantic jet is almost zonal and in a southern position (Fig. 12b and d); the upper branch of the cross-jet circulation is weaker over Africa and stronger over Europe (Fig. 12f), with reinforced rising motions over the westerncentral Mediterranean (Fig. 12h). Under these conditions, Northeast Africa is drier than normal.

\subsection{Spring}

In spring, the rainfall anomalies related to the jetstream variability show a north-south dipole. Detailing, when rainfall is anomalously abundant in Europe and North Africa is drier than normal, the Atlantic jet weakens and retreats over the ocean, and the African jet weakens and moves northwards (Fig. 13a, c). The upper branch of the cross-jet circulation is weaker over North Africa and stronger over Europe (Fig. 13e), with reinforced rising motions over Western Europe (Fig. 13g).

When rainfall is anomalously abundant in North Africa and Europe is drier than normal, the Atlantic jet is relatively strong, with a large northeasterly tilt whereas the African jet stays in a southern position, with a relatively strong intensity (Fig. 13b and d); the upper branch of the cross-jet circulation is weaker over Europe and stronger over North Africa (Fig. 13f), with reinforced rising motions over North Africa (Fig. 13h). 


\section{Conclusions}

The results show that the polarity of the NAO index determines the rainfall distribution between North Europe and South Europe, whereas the position and the intensity of the Atlantic jet, relative to the position and the intensity of the African jet, determines the rainfall distribution between the two Mediterranean basins, WM and EM. Our analysis shows that the Mediterranean rainfall is modulated by the vorticity advection in the upper troposphere and by the thermal advection in the lower troposphere of the respective cross-jet circulations of the Atlantic and African jets. The weather perturbations, initially driven by the CAPE and generated by the northwards thermal advection in the lower branch of the cross-jet circulation of the Atlantic jet, propagate upwards and eastwards. Downstream from the exit region of this jet, these perturbations spread horizontally: some of the storms move towards North Europe, and the remaining storms move towards the Mediterranean region, and the relative partition is determined by the NAO index. Since the circulation across the Atlantic jet favors storm activity while the circulation across the African jet inhibits this activity, it is the relative position of these two jets which determines the pattern of the weather systems entering into the Mediterranean region.

In fall, when the Atlantic jet strengthens, still keeping its small northeasterly tilt, the African jet stays relatively weak and in its eastern position; with this jetstream configuration, the rainfall is abundant in the WM. In addition, the WM is anomalously wet when the Atlantic jet is to the south of its fall mean position, and the African jet is to the east of its fall mean position; on the other hand, the WM is dryer when the Atlantic jet has a larger northeasterly tilt, and the African jet is stronger and more western than the fall average.

In winter, when both jets are rather strong, the Atlantic jet has a considerable northeasterly tilt, and the African jet covers the entire North African continent; with this configuration it rains more in the EM. The rainfall anomalies are mainly related to the latitudinal migration of the Atlantic jet, while the role of the African jet is less important. When the western-central Mediterranean is dryer than average, Northeast Africa experiences wet conditions, and the Atlantic jet moves to an anomalous northern position. The opposite rainfall anomaly pattern is related to a more southern jet position.

In spring, when the Atlantic jet weakens and retreats over the ocean and the African jet stays in its winter position, the rainfall is abundant in the Balkans and in the Alpine region. The precipitation anomalies in spring are mostly influenced by the African jet, while the role of the Atlantic jet is less important. In fact, when the African jet migrates northwards, the rainfall is anomalously abundant in Europe and negative anomalies are observed over the North African coast. When the African jet is in a more southern position, the signs of the anomalies are reversed.
Acknowledgements. NCEP Reanalysis and CMAP Precipitation data have been provided by the NOAA/OAR/ESRL PSD, Boulder, Colorado, USA, from their web site at http://www.esrl.noaa.gov/psd/. This work has been partially funded by the EU integrated project Climate Change and Impact Research: the Mediterranean Environment (CIRCE), project no. 036961, and by the CNR-CNRS Telemedaf joint Project. M. Baldi and G. A. Dalu acknowledge the support of the Italian CNR Short-Term Mobility Program. We thank the two reviewers and J. D. Dalu for their contributions to improving the manuscript.

Edited by: P. Lionello

Reviewed by: R. Trigo and another anonymous referee

\section{References}

Barnston, A. G. and Livezey, R. E.: Classification, seasonality and persistence of low-frequency atmospheric circulation patterns, Mon. Weather Rev., 115, 1083-1127, 1987.

Bjerknes, J.: Atlantic air-sea interaction, Adv. Geophys., 10, 1-82, 1964.

Branstator, G.: Circumglobal Teleconnections, the Jet Stream Waveguide, and the North Atlantic Oscillation, J. Climate, 15, 1893-1910, 2002.

Brody, L. R. and Nestor, M. J. R.: Handbook for forecasters in the Mediterranean, Part 2: Regional Forecasting Aids for the Mediterranean Basin, Naval Environmental Research Facility, Monterey, California, 1980.

Bryson, R. A.: The discovery of the jet stream, Wisconsin Academy Review, Summer, University of Wisconsin-Madison, 15-17, 1994.

Chen, T. H.: Maintenance of the Midtropospheric North African Summer Circulation: Saharan High and African Easterly Jet, J. Climate, 18, 2943-2962, 2005.

Deser, C. and Blackmon, M. L.: Surface climate variations over the Atlantic ocean during winter: 1900-1989, J. Climate, 6, 17431753, 1993.

Enfield, D. B., Mestaz-Nunez, A. M., and Trimble, P. J.: The Atlantic multidecadal oscillation and its relation to rainfall and river flows in the continental US, Geophys. Res. Lett., 28, 2077-2080, 2001.

Eshel, G. and Farrell, B. F.: Mechanisms of Eastern Mediterranean Rainfall Variability, J. Atmos. Sci., 57, 3219-3232, 2000.

Eshel, G. and Farrell, B. F.: Notes and Correspondence: Thermodynamics of Eastern Mediterranean Rainfall Variability, J. Atmos. Sci., 58, 87-92, 2001.

Grossmann, I. and Klotzbach, P. J.: A review of the North Atlantic modes of natural variability and their driving mechanisms, J. Geophys. Res., 114, D24107, doi:10.1029/2009JD012728, 2009.

Harnik, N. and Chang, E. K. M.: Stormtrack Variations As Seen in Radiosonde Observations and Reanalysis Data, J. Atmos. Sci., 16, 480-495, 2003.

HMSO: Weather in the Mediterranean I: General Meteorology, 2 Edn., Her Majesty's Stationery Office, 362 pp., 1962.

Holton, J. R.: An introduction to dynamic meteorology, Academic Press, 507 pp., 1992.

Hoskins, B. J., James, I. N., and White, G. H.: The shape, propagation and mean-flow interaction of large-scale weather systems, J. Atmos. Sci., 40, 1595-1612, 1983. 
Hulme, M., Barrow, E. M., Arnell, N. W., Harrison, P. A., Johns, T. C., and Downing, T. E.: Relative impacts of human-induced climate change and natural climate variability, Nature, 397, 688691,1999

Hurrell, J. W.: Decadal trends in the North Atlantic Oscillation: regional temperature and precipitation, Science, 269, 676-679, 1995.

Hurrell, J. W. and Deser, C.: North Atlantic climate variability: the role of the North Atlantic oscillation, J. Mar. Sys., 79, 231-244, 2010.

Hurrell, J. W., Kushnir, Y., Ottersen, G., and Visbeck, M.: An Overview of the North Atlantic Oscillation, in: The North Atlantic Oscillation: Climatic Significance and Environmental Impact, Geophysical Monograph, 134, American Geophysical Union, 2003.

Kanamitsu, M., Ebisuzaki, W., Woollen, J., Yang, S. K., Hnilo, J. J., Fiorino, M., and Potter, G.: NCEP-DOE AMIP-II reanalysis, Bull. Am. Meteorol. Soc., 83, 1631-1643, 2002.

Köppen, W.: Versuch einer klassifikation der alitate, vorzugweise nach ihren beziehungen zur pflanzenwelt, Geogr. Zeitschr., 6, 593-611, 657-679, 1900.

Kushnir, Y.: Interdecadal variations in North Atlantic sea surface temperature and associated atmospheric conditions, J. Climate, 7, 141-157, 1994.

Marshall, J., Kushnir, Y., Battisti, D., Chamg, P., Czaja, A., Dickson, R., Hurrell, J., McCartney, M., Saravanan, R., and Visbeck, M.: North Atlantic climate variability: phenomena, impacts and mechanisms, Int. J. Climatol., 21, 1863-1898, 2001a.

Marshall, J., Johnson, J. H., and Goodman, J.: A study of the interaction of the North Atlantic oscillation with the ocean circulation, J. Climate, 14, 1399-1421, 2001b.

Ogi, M., Tachibana, Y., and Yamazaki, K.: Impact of the wintertime North Atlantic Oscillation (NAO) on the summertime atmospheric circulation, Geophys. Res. Lett., 30, L01704, doi:10.1029/2003GL017280, 2003.

Ogi, M., Yamazaki, K., and Tachibana, Y.: The summer northern annular mode and the abnormal summer weather in 2003, Geophys. Res. Lett., 32, L04706, doi:10.1029/2004GL021528, 2005.

Reale, O., Feudale, L., and Turato, B.: Evaporate moisture sources during a sequence of floods in the Mediterranean region, Geophys. Res. Lett., 28, 2085-2088, 2001.

Rodwell, M. J. and Hoskins, B. J.: Monsoons and the dynamics of the deserts, Q. J. R. Meteorol. Soc., 122, 1385-1404, 1996.

Rodwell, M. J., Rowell, D. P., and Folland, C. K.: Oceanic forcing of the wintertime North Atlantic oscillation and climate variability of northern Europe, Nature, 10, 1635-1647, 1999.

Ruti, P., Lucarini, V., Dell'Aquila, A., and Calmanti, S.: Does the subtropical jet catalyze the midlatitude atmospheric regimes?, Geophys. Res. Lett., 33, L06814, doi:10.1029/2005GL024620, 2006.

Stephenson, D. B., Pavan, V., and Bojariu, R.: Is the North Atlantic oscillation a random walk?, Int. J. Climatol., 20, 1-18, 2000.
Trigo, I. F.: Climatology and interannual variability of stormtracks in the Euro-Atlantic sector: a comparison between ERA40 and NCEP/NCAR reanalyses. Clim. Dynam., 26, 127-143, doi:10.1007/s00382-005-0065-9, 2006.

Trigo, I. F., Davies, T. D., and Bigg, G. R.: Objective climatology of cyclones in the Mediterranean region, J. Climate, 12, 16851696, 1999.

Trigo, I. F., Bigg, G. R., and Davies, T. D.: Climatology of cyclogenesis mechanisms in the Mediterranean, Mon. Weather Rev. 130, 549-569, 2002.

Trigo, R., Xoplaki, E., Zorita, E., Luterbacher, J., Krichak, S., Alpert, P., Jacobeit, J., Saenz, J., Fernandez, J., GonzalezRouco, F., Garcia-Herrera, R., Rodo, X., Brunetti, M., Nanni, T., Maugeri, M., Turkes, M., Gimeno, L., Ribera, P., Brunet, M., Trigo, I., Crepon, M., and Mariotti, A.: Relations between variability in the Mediterranean region and Mid-latitude variability, in: Mediterranean Climate: an overview of the main characteristics and issues, edited by: Lionello, P., Malanotte-Rizzoli, P., and Boscolo R., Elsevier, Amsterdam, 179-226, 2006.

Uccellini, L. W. and Kocin, P. J.: The interaction of jet streak circulations during heavy snow events along the east coast of the United States, Weather Forecast., 1, 289-308, 1987.

Vallis, G. K. and Gerber, E.: Local and hemispheric dynamics of the North Atlantic Oscillation, annular patterns and the zonal index, Dyn. Atmos. Oceans, 44, 184-212, 2008.

van Loon, H. and Rogers, J. C.: The seesaw in winter temperatures between Greenland and Northern Europe, Part 1: general description, Mon. Weather Rev., 106, 296-310, 1978.

von Storch H. and Zwiers, F. W.: Statistical Analysis in Climate Research, Cambridge University Press, 1999.

Walker, G. T.: Correlations in seasonal variation of weather, Indian Meteorol. Mem., 24(VI), 275-332, 1924.

Wallace, J. M. and Gutzler, D. S.: Teleconnections in the geopotential field during the Northern Hemisphere winter, Mon. Weather Rev., 109, 784-812, 1981.

Wallace, J. M., Lim, G. H., and Blackmon, L. M.: Relationship between cyclones tracks, anticyclone tracks and baroclinic waveguides, J. Atmos. Sci., 45, 439-462, 1988.

Wunsch, C.: The interpretation of short climate records, with comments on the North Atlantic Oscillation and Southern Oscillations, Bull. Am. Meteorol. Soc., 80, 245-255, 1999.

Xie, P. and Arkin, P. A.: Global precipitation: a 17-year monthly analysis based on gauge observations, satellite estimates, and numerical model outputs, Bull. Am. Meteorol. Soc., 78, 25392558, 1997.

Xoplaki, E.: Climate variability over the Mediterranean, $\mathrm{PhD}$ thesis, University of Bern, Switzerland, 2002.

Ziv, B., Saaroni, H., Romem, M., Heifetz, E., Harnik, N., and Baharad, A.: Analysis of Conveyor Belts in Winter Mediterranean Cyclones, Theor. App. Clim., 99, 441-455, 2010. 